\title{
Factors that Affect Commitment to Continue Studies Among Business Students: A Comparative Study of Asian and Canadian Students studying in Canada
}

\author{
Amarjit Gill ${ }^{*}, 1$, Nahum Biger ${ }^{2}$, Chenping Pai $^{3}$, Rajendra Tibrewala ${ }^{4}$ and Vivek Nagpal ${ }^{5}$ \\ ${ }^{1}$ College of Business Administration, TUI University, CA, 90630, USA \\ ${ }^{2}$ College of Business Administration, TUI University, CA, 90630, USA \\ ${ }^{3}$ School of Management, New York Institute of Technology, NY, USA \\ ${ }^{4}$ School of Management, New York Institute of Technology, NY, USA \\ ${ }^{5}$ Mission Convergence under GNCT in the Office of the Deputy Commissioner (West), Delhi, India
}

\begin{abstract}
This paper examines the effects of transformational leadership and of stress on students' commitment to continue their college or university studies. Asian and Canadian students enrolled in business management program at colleges and universities in British Columbia, Canada were surveyed to gauge their perceptions as to whether transformational leadership used by faculty members and stress affect their commitment to continue studies. The results suggest that when instructors implement transformational leadership, such behavior positively affects the perceived student commitment to continue their studies. Some differences in this relationship were found between Asian students and Canadian students. The effect of transformational leadership on students' willingness to continue their studies was found to be stronger among Asian students who were also less affected by stress. This paper offers useful empirically based insights for instructors.
\end{abstract}

Keywords: Transformational leadership, student stress, commitment to continue studies by students, Asian students, Canadian students.

\section{INTRODUCTION}

The paper examines the effects of instructors and professors' transformational leadership (TL) and student stress (SS) on students' commitment to continue their studies.

Business motives have led Organization for Economic Cooperation and Development (OECD) countries to liberalize their policies to increase import and export in education, which in turn, increased number of international students in North American countries. The international market for educational services has to a large extent been demand-driven, particularly by students from the rapidly emerging countries of North and South-East Asia [1]. Most international trade in higher education services takes place within the OECD area, which received $85 \%$ of the world's foreign students [1]. Thus, foreign students represent an important source of export revenue for the North American colleges and universities particularly the United States of America and Canada.

Although foreign students represent an important source of export revenue, they create some challenges for colleges and universities due to their different learning styles, behaviors, cultures, and attitudes, which in turn, lead to student leadership issues and challenges for instructors/professors [2]. Consequently, international students tend to get dissatisfied with educational programs and get "stressed out" which

*Address correspondence to this author at the College of Business Administration, TUI University, CA, 90630, USA; E-mail: AGill@tuiu.edu lead to their withdrawal from the educational programs countering the educational export efforts of North American colleges/universities.

Different learning styles, behaviors, cultures, and attitudes of Canadian students also impact on retention rate. Giselle [3] indicates that Canada is experiencing an increase in the number of students considered to be at-risk for academic failure. The threat of academic failure leads to high level of student stress, which in turn, increase student turnover. Research has shown that half of all adults seeking education dropout before their coursework is completed [4]. Therefore, it is important to find solutions to threat of academic failure issues to reduce student turnover. Because of the different student learning styles, behaviors, and attitudes, instructors'/professors' role has been changed from just teachers to learning coaches. Coaching reduces the students' stress resulting from study, which in turn, improves student retention.

Transformational leadership when employed by instructors/professors holds great promise for colleges and universities because it can be used to enhance student commitment to continue studies. The concept and definition of transformational leadership and the embodiment of that leadership in transformational leaders were coined by Burns [5].

Different authors [6-8] have found positive relationship between transformational leadership and individual commitment/dedication towards organizations. The concept of 
organizational commitment appears prominently in the research literature [9]. However, there has been very little research conducted testing the relationship between transformational leadership by college instructors and university professors and students' commitment to continue their studies. Research on stress began as a result of work conducted on emotion, arousal, and the way in which people manage the arousal [10]. Since that time period, little research has been conducted to test relationship between stress and commitment variables. Mikkelsen et al. [11] found the positive relationship between job stress and commitment. Piotrowski and Plash [12] indicate that stress is one of the major factors that lead to high turnover; that is, the higher level of stress leads to higher student turnover and vice versa. Thus, stress has a negative impact on students' commitment to continue their studies, which in turn, increase student turnover. Therefore, it is important to examine the relationship between: i) instructors' transformational leadership and students' commitment to continue their studies and ii) student stress and students' commitment to continue their studies within an educational setting. The findings of said examination can be generalized to the broader educational field.

\section{TRANSFORMATIONAL LEADERSHIP AND STU- DENT COMMITMENT TO CONTINUE STUDY}

Similar to the importance for the for-profit companies to satisfy customers in order to retain them, satisfying matriculated students is equally important for student retention purposes [13]. Factors such as: i) faculty support to students, ii) quality of education, iii) faculty teaching styles, etc., have positive impact on student educational satisfaction [14-16]. Student educational satisfaction increase students' commitment to continue their studies [17].

Klassen [18] argues that the Indo-Canadian students are more vertical or hierarchical than the Anglo-Canadian students and that comparison with others strongly influences their motivation beliefs and the formation of their efficacy beliefs. Self-efficacy (students' beliefs about their capabilities to produce effects) in Asian culture may be less otheroriented (values that concern on the welfare of others, i.e., pro-social, collective morality, concern for others, etc.) than is typically seen in Western cultures. Low self-efficacy of students creates challenges for North American instructors/professors. Low efficacy also has a negative impact of students' commitment to continue their studies because of the threat of academic failure.

Transformational leadership has been found to encourage open communication with followers, which in turn, enhance students' commitment to continue their studies. The term transformational leadership is defined as the process of influencing major changes in the attitudes and assumptions of students and building their commitment to continue their studies. This definition emphasizes the importance of leadership characteristics, such as an instructor's ability to define and articulate a set of course goals and objectives. The definition also stresses the importance of the followers' (e.g., students') acceptance of the leader (instructor/professor). Gill and Mathur [7] and Herold et al. [8] found positive relationships between transformational leadership and organizational commitment.
Transformational leadership has strong relationships with teacher motivation and student outcomes [19]. A subset of motivation is students' commitment to continue their studies. Students who are committed to their college/university help socialize new students and they speak positively about their educational institution to outsiders. However, student study motivation can be different at the undergraduate and graduate levels; that is, the graduate level students can be motivated to finish their homework more than the undergraduate level students because of the level of maturity.

Asian and Canadian students face many education related issues such as an unclear course or program mission or weakly defined goals and objectives, due to poor leadership demonstrated by their instructors/professors in their study environments. Such issues contribute to dissatisfaction with education. We pointed out that transformational leadership was found to improve commitment towards an organization by increasing positive attitudes and clarifying the role of employees [20-22]. In the educational context, it is theorized that Asian and Canadian students' commitment to continue their studies is related to the degree of their understanding of educational goals and objectives, which are outcomes of instructors' transformational leadership style.

Hence, the following hypotheses were formulated:

H1: The more an instructor's leadership is perceived as being transformational, the higher will be the commitment of Asian students to continue their studies at the Canadian colleges and universities.

H2: The more an instructor's leadership is perceived as being transformational, the higher will be the commitment of Canadian students to continue their studies at the Canadian colleges and universities.

\section{THE IMPACT OF STRESS ON COMMITMENT OF STUDENTS TO CONTINUE THEIR STUDIES}

Stress, a mental and physical condition, affects students' effectiveness, personal health, and quality of home work. Stress is seen as the consequence of an inadequate fit of student needs and goals with the college environment [23].

Students are faced with many challenges such as heavy course loads, loneliness, conflict with roommates, etc., on a daily basis at colleges [24], which in turn, cause stress for students. When stress is perceived negatively or becomes excessive, students experience physical and psychological impairment [25], which has a negative impact on their academic performance. Poor academic performance leads to high student turnover. Therefore, the harmful and costly consequences of stress demonstrate the need for strategies to limit stressors within the organization [26]. Transformational leadership, as one such strategy, has been found to encourage open communication with followers, which, in turn, reduces stress [27]. Reduced stress, in turn, improves students' commitment to continue their studies.

A disturbing trend in student health is the reported increase in student stress nationwide [28]. One of the stressors affecting students can be categorized as academic [29]. Academic stressors include the student's perception of the extensive knowledge base required and the perception of an inadequate time to develop it [30]. Students report experiencing academic stress at predictable times each semester with 
the greatest sources of academic stress resulting from taking and studying for exams, grade competition, and the large amount of content to master in a small amount of time [3134], which in turn, create student retention issues. Thus, stress has negative impact on student commitment. Therefore, it is important to reduce student stress to improve student commitment.

Sinha et al. [35] findings suggest that there are more similarities than differences among Indian and Canadian university students in respect of stress, coping, and related psychosocial variables. The differences, however, reflect the impact of culture. Regional variations are more pronounced in India than in Canada.

Asian and Canadian students are subjected to the constant pressure of schoolwork, friends, instructors/professors, tests, quizzes, papers, and many times unplanned or unforeseen peaks in their study environments - all of which contribute to higher levels of study related stress. Students who are committed to their study mission, goals, and objectives (transformational leadership outcomes) feel less study stress, which in turn, improves students' commitment to continue their studies.

Accordingly, the following hypotheses were formulated:

H3: The lower the level of stress, the higher the level of Asian students' commitment to continue their studies at the Canadian colleges and universities.

H4: The lower the level of stress, the higher the level of Canadian students' commitment to continue their studies at the Canadian colleges and universities.

\section{METHODS}

\section{Research Design}

This study utilized a survey research (a non-experimental field study design), appropriate to examine the research questions and test their derivative hypotheses. Gall et al. [36] also indicate that a survey research is a useful tool for studying sensitive opinions, attitudes, preferences, and behaviors of individuals, particularly when the opinions are reflections of larger underlying attitudinal constructs.

\section{Measurement and Variables}

Consistent with previous research, the measures were adopted from three referent studies which were based on previous studies in marketing, education, and psychology. Measures pertaining to transformational leadership were adopted from Dubinsky et al. [37] and Griffith [38]. Measures pertaining to students' commitment to continue their studies were adopted from Thomas [39], and measures pertaining to student stress were adopted from Dubinsky et al. [37].

The questionnaire was pre-tested to ensure that it was effective in a pilot study conducted with 30 representative (of the full pool of respondents) students.

Transformational leadership (TL) was operationally defined as the extent to which instructors/professors motivate and encourage students to use their own judgment and intelligence to solve education related problems, transfer missions to students, and express appreciation for good work. Dubinsky et al. [37] used the twelve-item tolerance- of-freedom scale [40] which measures a sales person's relationship with managers. Griffith [38] used four items that measured intellectual stimulation of teachers. Based on these two studies CFA (confirmatory factor analysis) two items from each study were selected to measure the "transformational leadership" variable in this study. Scale items were reworded to apply to students in the education field and the reliability of these re-worded items was re-tested. These items are:

To what extent does your instructor/professor...?

TL1) ... make you proud to be associated with him or her?

TL2) ... encourage you to study?

TL3) ... transmit a "sense of mission" to you?

TL4) ... let you use your intelligence to overcome obstacles in the classroom and outside the classroom?

Respondents were asked to indicate their agreement with each item using a four-point Likert scale ranging from "None" to "Extreme." Higher scores indicate that students have a closer relationship with their instructors/professors.

Griffith [38] reported Cronbach alpha of 0.89 for the above 2 items. Cronbach alpha was not reported by Dubinsky et al. [37] for the above 2 items. We calculated a Cronbach alpha of .80 on the responses of the 30 students who participated in the pre-test of this scale. Based on the scales reliability, we included all four items in our final questionnaire.

Student Stress (SS) was operationally defined as the extent to which students feel a tension or anxiety caused by their studies. Dubinsky et al. [37] used the two stress items developed by Motowidlo et al. [41]. Based on the CFA reported by Dubinsky et al. [37], both items were selected to measure the "student stress" variable. Scale items were reworded to apply to students in the education field and the reliability of these re-worded items was re-tested. These items are:

To what extent do you feel...?

SS1) ... tense because of your studies?

SS2) ... nervous because of your studies?

Respondents were asked to indicate their agreement with each item, using a four-point Likert scale ranging from "None" to "Extreme." Higher scores reflect a higher level of stress perceived by the students.

Cronbach alpha was not reported by Dubinsky et al. [37] for the above 2 items. We calculated a Cronbach alpha of .79 on the responses of the 30 students who participated in the pre-test of this scale. Based on the scales reliability, we included both items in our final questionnaire.

Students' Commitment to continue their studies was operationalized as the extent to which students are committed to a college/university to earn a higher degree in near future. Thomas [39] used four-item tolerance-of-freedom scale which measures student commitment to a college/university. Based on their CFA loading scores three of the four items were selected to measure the "students' commitment to continue their studies" variable. Scale items were reworded to apply to stu- 
dents in the education industry and the reliability of these reworded items was re-tested. These items are:

To what extent ...?

SC1) ... do you tell your friends that this college/university is a great place to study?

SC2) $\ldots$ is it important to you to graduate from this college/university?

SC3) ... do you plan to continue study at this college/university to earn a higher degree in the future?

Respondents were asked to indicate their agreement with each item, using a four-point Likert scale ranging from "None" to "Extreme." Higher scores indicate higher level of commitment to continue their studies of students at present college/university in near future.

Thomas [39] reported a Cronbach alpha of .71 for the above four items. We calculated a Cronbach alpha of .86 on the responses of the thirty students who participated in the pre-test of the above scale items. All three items were included in the final questionnaire.

\section{Sampling Frame, Questionnaire Distribution, and Collec- tion}

The study's pool of subjects includes only (to avoid sampling frame issues) both Asian and Canadian students attending colleges and universities in the Lower Mainland of the British Columbia, Canada area (Vancouver, Burnaby, New Westminster, Surrey, and Richmond).

\section{Sampling Methods and Issues}

A list of all academic institutions (colleges and universities) in the Lower Mainland area from which a mailing list was compiled of faculty and students. Survey questionnaires were distributed to these students. As some of the academic institutions were reluctant to provide us with their full student rosters, we need define this subject recruitment method as a convenience (non-random) sampling method.

To mitigate possible sampling bias (the threat to representational ability of a sample) the team of data collectors were guided to ensure that subjects met inclusion criteria: country of origin (Canadian and South East Asia), study program (Business undergraduate, graduate, certificate and diploma), etc.

From our sample population pool of about 2000 student who met all inclusion criteria 422 fully completed survey questionnaires (a response rate of $21.25 \%$ ).

The confidentiality of all subjects was assured by having them respond anonymously to the questionnaires. All subjects of the study participated voluntarily.

\section{ANALYSIS AND RESULTS}

A linear regression was utilized to test our hypotheses. Furthermore, by categorizing the subject students into two major country origin groups of Canadians and Asians, we analyzed differences between domestic and foreign students.

\section{Data Analysis Methods}

Tables 1, 2 show statistics describing student responses. Student data were treated to the same tests of skewness.
Skewness measures for all of the items were within the range of -1.0 to +1.0 .

Using principle component rotation and varimax rotation, a Confirmatory Factor Analysis (CFA) on the nine items was run. Three factors explained $77.56 \%$ (Table 3 ) of the variance in the nine items, and all of the items loaded on the expected factors (Table 4).

Factor analysis was used because we asked our respondents multiple questions. We expected some of the responses to be independent on other responses and we expected some of the responses to be dependent on other responses. We used factor analysis to make sure that the variables we thought were independent of those variables and to make sure that the variables that we thought were dependent of other variables were dependent of those variables. The factor scores we created insured the variables we thought were independent of other variables were independent of those variables and that the variables that we thought were dependent of other variables were dependent of those variables.

The four "transformational-leadership" items were factor analyzed, and the resultant weighted score was used as the "transformational leadership" scale. The four items loaded roughly equally on the scale, and explained $78.66 \%$ of the variance. Cronbach alpha calculated was 0.91 on the four items.

The three "students' commitment to continue their studies" items were factor analyzed and the resultant weighted score was used as our "students' commitment to continue their studies" scale. The three items loaded roughly equally on the scale. This factor explained $66.40 \%$ of the variance in the three items. Cronbach alpha calculated was 0.75 on the three items.

The two "student stress" items were factor analyzed, and the resultant weighted score was used as the "student stress" scale. The two items loaded roughly equally on the scale, and explained $89.06 \%$ of the variance. Cronbach alpha calculated was 0.88 on the two items.

\section{Testing of Hypotheses}

\section{Study Descriptives}

The $n=422$ student subjects break up into the following groups (Table 5):

- Country of origin: Canada (51\%), South East Asia (49\%) - half of whom came from China.

Table 6 presents the pair-wise correlation coefficients between the three variables. Student commitment was found to be highly correlated with transformational leadership and negatively albeit not significantly correlated with Student stress.

Table 7 displays the linear (multiple) regression results for the entire sample. There are three 'explanatory variables' to the dependent variable "Student Commitment." Instructors' "Transformational Leadership" is highly significant and so is the 'dummy variable' that is the country of origin. Canadian students were marked as 0 while Asian students are marked as 1 . The significant regression coefficient of the dummy variable implies that there are two significantly different groups in their commitment to continue their 
Table 1. Undergraduate Student Data Statistics

\begin{tabular}{|c|c|c|c|c|}
\hline & \multicolumn{4}{|c|}{ Education Program } \\
\hline & \multirow{2}{*}{\multicolumn{2}{|c|}{$\begin{array}{l}\begin{array}{c}\text { Undergraduate } \\
\mathrm{N}=95\end{array} \\
\text { Region - Asia }\end{array}$}} & \multirow{2}{*}{\multicolumn{2}{|c|}{$\begin{array}{c}\begin{array}{c}\text { Undergraduate } \\
\mathbf{N}=\mathbf{2 0 5}\end{array} \\
\text { Region - North } \\
\text { America (Canada) }\end{array}$}} \\
\hline & & & & \\
\hline To what extent...? & Mean & $\begin{array}{l}\text { Standard } \\
\text { Deviation }\end{array}$ & Mean & $\begin{array}{l}\text { Standard } \\
\text { Deviation }\end{array}$ \\
\hline 1) ... do your instructors/professors make you proud to be associated with them? & 3.00 & 0.911 & 2.45 & 0.788 \\
\hline 2) ... do your instructors/professors encourage you to study? & 3.08 & 0.808 & 2.73 & 0.769 \\
\hline 3) ... do your instructors/professors transmit a "sense of mission" to you? & 2.96 & 0.910 & 2.58 & 0.774 \\
\hline 4) ... do your instructors/professors let you use your intelligence to overcome obstacles in the classroom? & 2.99 & 0.881 & 2.67 & 0.752 \\
\hline 5) ... do you tell your friends that this college/university is a great place to study? & 2.93 & 0.902 & 2.60 & 0.883 \\
\hline 6) ... is it important to you to graduate from this college/university? & 3.11 & 0.844 & 3.24 & 0.885 \\
\hline 7) ... do you plan to continue study at this college/university to earn a higher degree in the future? & 2.98 & 0.887 & 2.49 & 1.041 \\
\hline 8) ... do you feel tense because of your study? & 2.19 & 1.065 & 2.80 & 0.991 \\
\hline 9) ... do you feel nervous because of your study? & 2.05 & 0.972 & 2.47 & 1.017 \\
\hline
\end{tabular}

Table 2. Graduate Student Data Statistics

\begin{tabular}{|c|c|c|c|c|}
\hline & \multicolumn{4}{|c|}{ Education Program } \\
\hline & \multirow{2}{*}{\multicolumn{2}{|c|}{$\begin{array}{c}\begin{array}{c}\text { Graduate } \\
\mathbf{N}=109\end{array} \\
\text { Region - Asia }\end{array}$}} & \multirow{2}{*}{\multicolumn{2}{|c|}{$\begin{array}{c}\text { Graduate } \\
\mathrm{N}=13 \\
\begin{array}{c}\text { Region - North } \\
\text { America (Canada) }\end{array}\end{array}$}} \\
\hline & & & & \\
\hline To what extent... & Mean & $\begin{array}{l}\text { Standard } \\
\text { Deviation }\end{array}$ & Mean & $\begin{array}{l}\text { Standard } \\
\text { Deviation }\end{array}$ \\
\hline 1) ... do your instructors/professors make you proud to be associated with them? & 2.83 & 0.768 & 2.92 & 1.115 \\
\hline 2) ... do your instructors/professors encourage you to study? & 3.02 & 0.694 & 3.31 & 0.751 \\
\hline 3) ... do your instructors/professors transmit a "sense of mission" to you? & 2.91 & 0.752 & 3.08 & 0.954 \\
\hline 4) ... do your instructors/professors let you use your intelligence to overcome obstacles in the classroom? & 2.88 & 0.766 & 3.23 & 0.927 \\
\hline 5) ... do you tell your friends that this college/university is a great place to study? & 2.60 & 0.883 & 3.23 & 0.832 \\
\hline 6) ... is it important to you to graduate from this college/university? & 2.88 & 0.802 & 3.92 & 0.277 \\
\hline 7) ... do you plan to continue study at this college/university to earn a higher degree in the future? & 2.50 & 0.978 & 3.23 & 0.832 \\
\hline 8) ... do you feel tense because of your study? & 2.40 & 0.973 & 2.54 & 1.050 \\
\hline 9) ... do you feel nervous because of your study? & 2.32 & 1.053 & 2.54 & 1.198 \\
\hline
\end{tabular}

$\mathrm{N}=$ Number of responses.

studies. The variable "Student Stress" was found not to be significant with $\mathrm{p}=0.253$.

In order to verify these results, we performed a step-wise regression. Table $\mathbf{8}$ presents the results. When the only explanatory variable is (Instructors') "Transformational Leadership," the $\mathrm{R}^{2}$ is 0.307 and the Adjusted $\mathrm{R}^{2}$ is only slightly less (0.305). When the second variable - "Country of Origin" (the dummy variable) enters both $\mathrm{R}^{2}$ and the Adjusted $\mathrm{R}^{2}$ rise, and the variable "Student Stress" does not enter the regression equation.
Table 3. Total Variance Explained - Rotation Sums of Square Loadings

\begin{tabular}{|c|c|c|c|}
\hline \multirow{2}{*}{ Component } & \multicolumn{3}{|c|}{ Total Variance Explained } \\
\cline { 2 - 4 } & \multicolumn{3}{|c|}{ Rotation Sums of Squared Loadings } \\
\cline { 2 - 4 } & Total & \% of Variance & Cumulative \% \\
\hline \hline 1 & 3.128 & 34.757 & 34.757 \\
\hline 2 & 2.026 & 22.508 & 57.265 \\
\hline 3 & 1.826 & 20.293 & 77.558 \\
\hline
\end{tabular}


Table 4. Rotated Component Matrix

\begin{tabular}{|c|c|c|c|}
\hline \multirow{2}{*}{ To what extent...? } & \multicolumn{3}{|c|}{ Component } \\
\hline & 1 & 2 & 3 \\
\hline 1) ... do your instructors/professors make you proud to be associated with them? & 0.791 & 0.297 & -0.158 \\
\hline 2) ... do your instructors/professors encourage you to study? & 0.874 & 0.201 & -0.090 \\
\hline 3) ... do your instructors/professors transmit a "sense of mission" to you? & 0.889 & 0.188 & -0.093 \\
\hline 4) ... do your instructors/professors let you use your intelligence to overcome obstacles in the classroom? & 0.825 & 0.264 & -0.131 \\
\hline 5) ... do you tell your friends that this college/university is a great place to study? & 0.345 & 0.722 & -0.061 \\
\hline 6) ... is it important to you to graduate from this college/university? & 0.109 & 0.842 & 0.107 \\
\hline 7) ... do you plan to continue study at this college/university to earn a higher degree in the future? & 0.314 & 0.749 & -0.119 \\
\hline 8) ... do you feel tense because of your study? & -0.162 & -0.020 & 0.930 \\
\hline 9) ... do you feel nervous because of your study? & -0.107 & -0.010 & 0.934 \\
\hline
\end{tabular}

Extraction Method: Principal Component Analysis. Rotation Method: Varimax with Kaiser Normalization. Rotation converged in 5 iterations.

The results reported in Table $\mathbf{8}$ indicate that there are actually two parallel regression lines. For Canadian students the regression equation is:

For Canadian born students:

Commitment to Continue Studies $=-0.137+0.583$ TL

Table 5. Descriptive Statistics - Country of Origin of Students

\begin{tabular}{|c|c|c|}
\hline Country of Origin & Number of Students & Percent \\
\hline \hline All & 422 & 100.0 \\
\hline Canada & 217 & 51.4 \\
\hline China & 113 & 26.8 \\
\hline Taiwan & 38 & 9.0 \\
\hline India & 33 & 7.8 \\
\hline Korea & 21 & 5.0 \\
\hline
\end{tabular}

Table 6. Pair-Wise Correlations of Variables - All Students

\begin{tabular}{|c|c|c|c|}
\hline \multicolumn{2}{|c|}{} & $\begin{array}{c}\text { Student } \\
\text { Commitment }\end{array}$ & $\begin{array}{c}\text { Student } \\
\text { Stress }\end{array}$ \\
\hline \hline $\begin{array}{c}\text { Transformational- } \\
\text { Leadership }\end{array}$ & $\begin{array}{c}\text { Pearson } \\
\text { Correlation }\end{array}$ & $0.554(* *)$ & $-0.273(* *)$ \\
\hline $\begin{array}{c}\text { Student } \\
\text { Commitment }\end{array}$ & $\begin{array}{c}\text { Sig. } \\
\text { P-tailed) }\end{array}$ & 0.000 & 0.000 \\
\hline \multicolumn{2}{|c|}{ Correlation } & -0.089 \\
\hline & Sig. (2-tailed) & & 422 \\
\hline
\end{tabular}

For Asian born students:

Commitment to Continue Studies $=+0.129+0.583$ TL

Thus, Asian born student have a higher tendency to continue to study in the same institution of higher education even in the absence of instructors' transformational leadership behavior.

It will be noted that when separate regressions were performed the results are a bit different and less reliable because running two separate regressions one for Asian students and one for Canadian born students would be conducted with substantially smaller number of degrees of freedom.

It was noted earlier that the step-wise regression revealed that for the entire sample the variable "Student Stress" was found to be non-significant. We tried to examine this issue by considering separately the Asian born and the Canadian born students.

Table 9 present the simple regression results regarding the linear relationship between "Student Stress" and "Commitment to Continue to Study" for Asian students. For these students the variable "Student Stress" is significant and has a negative association with the tendency to continue to study. The regression equation for these students is:

Commitment to continue studies $=-0.038-0.16$ Student Stress

Where the negative regression coefficient of the variable "Student Stress" is statistically significant (Sig. = 0.031).

The same regression for Canadian student yielded no significant results.

\section{DISCUSSION}

The main purpose of this study was to examine whether students' commitment to continue their studies at the Canadian colleges and universities is related to the degree of transformational leadership used by instructors/professors and study stress. We also examined the extent to which there is a difference between these relationships when we compare two groups of students: Asian and Canadian

For the entire sample $(n=422)$ it was found that the degree of perceived commitment to continue their studies in their college or university is related to the degree of transformational leadership used by instructors/professors at their educational institutions. This lends the support to the finding of previous authors [6-8] who found that in a non- 
Table 7. Regression Results - Entire Sample

$$
R=0.571 ; R^{2}=0.326 ; \text { Adj } R^{2}=0.321 ; \text { SEE }=0.8239
$$

\begin{tabular}{|c|c|c|c|c|c|c|}
\hline \multirow{2}{*}{ Model } & & \multicolumn{2}{|c|}{ Unstandardized Coefficients } & \multirow{2}{*}{$\frac{\text { Standardized Coefficients }}{\text { Beta }}$} & \multirow{2}{*}{$\mathbf{t}$} & \multirow{2}{*}{ Sig. } \\
\hline & & B & Std. Error & & & \\
\hline \multirow[t]{4}{*}{1} & (Constant) & -0.130 & 0.059 & & -2.213 & 0.027 \\
\hline & Transformational-Leadership & 0.595 & 0.042 & 0.595 & 14.031 & 0.000 \\
\hline & Student Stress & 0.048 & 0.042 & 0.048 & 1.144 & 0.253 \\
\hline & Country of Origin $($ Asia $=1 ;$ Canada $=0)$ & 0.252 & 0.083 & 0.126 & 3.028 & 0.003 \\
\hline
\end{tabular}

Dependent Variable: Student Commitment.

Table 8. Step-Wise Regression for the Entire Sample

Model Summary

\begin{tabular}{|c|c|c|c|c|}
\hline Model & R & R Square & Adjusted R Square & Std. Error of the Estimate \\
\hline \hline 1 & $0.554^{\mathrm{a}}$ & 0.307 & 0.305 & 0.8334 \\
\hline 2 & $0.569^{\mathrm{b}}$ & 0.324 & 0.321 & 0.8242 \\
\hline
\end{tabular}

${ }^{a}$ Predictors: (Constant), Transformational-Leadership.

${ }^{\mathrm{b}}$ Predictors: (Constant), Transformational-Leadership, Asia and North America (Canada).

\begin{tabular}{|c|c|c|c|c|c|c|}
\hline \multirow{2}{*}{ Model } & & \multicolumn{2}{|c|}{ Unstandardized Coefficients } & \multirow{2}{*}{$\begin{array}{c}\text { Standardized Coefficients } \\
\text { Beta }\end{array}$} & \multirow{2}{*}{$\mathbf{t}$} & \multirow{2}{*}{ Sig. } \\
\hline & & B & Std. Error & & & \\
\hline \multirow[t]{2}{*}{1} & (Constant) & 2.99 & 0.041 & & 0.000 & 1.000 \\
\hline & Transformational-Leadership & 0.554 & 0.041 & 0.554 & 13.642 & 0.000 \\
\hline \multirow[t]{3}{*}{2} & (Constant) & -0.137 & 0.058 & & -2.348 & 0.019 \\
\hline & Transformational-Leadership & 0.583 & 0.041 & 0.583 & 14.166 & 0.000 \\
\hline & Country of Origin $($ Asia $=1 ;$ Canada $=0)$ & 0.266 & 0.082 & 0.133 & 3.228 & 0.001 \\
\hline
\end{tabular}

Dependent Variable: Student Commitment.

educational context there is a positive relationship between transformational leadership and commitment.

We also found that there is a significant difference between the two groups of students. Asian students who study in Canadian colleges or universities tend to be more resilient in their tendency to continue their studies in the same institution of higher learning irrespective of the instructors' style. Instructor's leadership style was found to be positively related to the tendency to continue the studies in a similar way to both groups of students.

Table 9. Asian Students' Commitment to Continue their Studies as a Function of Student Stress ${ }^{\text {a, b }}$

\begin{tabular}{|c|c|c|c|c|c|}
\hline & $\begin{array}{c}\text { Unstandardized } \\
\text { Coefficients }\end{array}$ & $\begin{array}{c}\text { Std. } \\
\text { Error }^{-}\end{array}$ & $\begin{array}{c}\text { Standardized } \\
\text { Coefficients }^{\mathbf{c}}\end{array}$ & $\mathbf{t}$ & Sig. \\
\hline \hline (Constant) & -0.038 & 0.075 & & -0.504 & 0.615 \\
\hline B & -0.160 & 0.073 & -0.151 & -2.176 & 0.031 \\
\hline
\end{tabular}

${ }^{a}$ Dependent Variable: Commitment to continue their studies.

${ }^{\mathrm{b}}$ Independent Variables: Student Stress.
We also found that among Asian students there was a statistically significant negative relationship between students' stress and their commitment to continue their studies. No significant relationship between students' stress and commitment to continue their studies was found among $\mathrm{Ca}$ nadian students. This may be due to the fact that Canadian students are more used to and expect the challenges at the Canadian colleges and universities. Findings from the Canadian students' data lend some support to Mikkelsen et al. [11] and Piotrowski and Plash's [12] research in which they found, in a different context, positive relationship between job stress and commitment.

Students play a boundary-spanning role where they interact with many individuals from inside (fellow students, administrative staff, and instructors/professors) and outside (employers) their college/university. This large role set requires students to satisfy frequently variegated needs and expectations of multiple parties (only one of which is their instructor/professor) which may lead to dissatisfaction with education experience. Student dissatisfaction with education leads to lower the student commitment to continue studies. Given these findings, we may conclude that North American colleges/universities could improve student retention by ad- 
vocating instructors to adopt transformational leadership style.

\section{Implementing Transformational Leadership Behaviors}

Although transformational leadership enhance students' commitment to continue their studies, there are some barriers that can make it difficult to implement transformational leadership approaches (e.g., lack of student's understanding of the course goals and objectives, communication barriers, lack of time, cultural barriers, instructors' understanding the degree to which transformational leadership needs to be implemented, etc.).

To overcome with above challenges, instructors need to communicate the course goals and objectives to students by "breaking-them-down" for each individual student. They should foster upward as well as downward communication. Practicing effective listening skills (e.g., showing students that you want to listen, being patient, holding your temper, going easy on argument and criticism, and asking relevant questions) can go a long way toward demonstrating respect and concern for students' personal feelings as well as overcoming communication and cultural barriers. Ultimately, instructors/professors should act as mentors (e.g., educate, advise, coach, support, and encourage) to students to fully overcome "the degree to which TL needs to be implemented" barriers.

All of the above require instructors/professors to internalize the importance of showing genuine concern and respect for students and their learning styles. In practice, although it may be difficult for some instructors/professors to increase their use of these transformational leadership behaviors and some students may eye a change in teaching styles with skepticism, the potential benefits far outweigh the costs, and such behaviors are develop-able. The importance of such a leadership development process, however, must be championed and strongly supported by senior leadership (e.g., the dean).

\section{Recommendations for Future Research}

Although this study clearly shows that Asian and Canadian students' commitment to continue their study is related to the degree of transformational leadership used by instructors/professors, additional research issues and questions must be addressed.

The possible variables that should be researched include:

- $\quad$ The degree to which instructors/professors understand the consequences of using transformational leadership and their desire to use it,

- $\quad$ The degree to which instructors/professors understand the desire of their students to accept transformational leadership,

- The degree to which students desire to accept transformational leadership from their instructors/professors,

- $\quad$ The degree to which instructors/professors understand the students' commitment to continue their studies, and

- $\quad$ The degree to which instructors/professors understand the student stress resulting from studies.
Furthermore, as discussed above, a more in-depth look at foreign students' maturity, possible preparation for academic studies, and their personal expectations from their studies may provide additional insight as to their perceptions of satisfaction and stress levels.

\section{REFERENCES}

[1] Larsen K, Vincent-Lancrin S. The learning business: can trade in international education work? OECE Observer 2002; 235: 26-9.

[2] Salvarajah C. Cross-cultural study of Asian and European student perception: the need to understand the changing educational environment in New Zealand. Cross Cult Manag 2006; 13:142-50.

[3] Giselle S. A model of individual and family factors related to achievement. Canada: University of Calgary 2006.

[4] Saltman JM. Humor in adult learning: A review of perceptions. Teachers College, Columbia University: New York 1995.

[5] Burns JM. Leadership, New York, Harper, \& Row: 1978.

[6] Lee J. Effects of leadership and leader-member exchange on commitment. Leadersh Organ Dev J 2005; 26: 655-73.

[7] Gill A, Mathur N. Improving employee dedication and pro-social behavior. Int J Contemp Hosp Manag 2007; 19: 328-34.

[8] Herold DM, Fedor DB, Caldwell S, Liu Y. The effects of transformational and change leadership on employees' commitment to a change: a multilevel study. J Appl Psychol 2008; 93: 346-56.

[9] Carmeli A, Freund A. Work commitment, job satisfaction, and job performance: an empirical investigation. Int $\mathrm{J}$ Organ Theory Behav 2004; 7: 289-310.

[10] Cordes CL, Dougherty TW. A review and an integration of research on job Burnout. Acad Manag Rev 1993; 18: 621-65.

[11] Mikkelsen A, Ogaard T, Lovrich N. Modeling the effects of organizational setting and individual coping style on employees subjective health, job satisfaction and commitment. Public Adm Q 2000; 24: 371-98.

[12] Piotrowski C, Plash SH. Turnover and the educational consultant: an OD intervention perspective. Organ Dev J 2006; 24: 22-8.

[13] DeShields OW, Jr, Kara A, Kaynak E. Determinants of business student satisfaction and retention in higher education: applying Herzberg's two-factor theory. Int J Educ Manag 2005; 19:128-40.

[14] Poirier D. The field-dependence/field-independence dimensions of cognitive style as a correlate of Success in post-secondary business and industrial arts programs [Online]. 1997. Available from: http://proquest.umi.com/pqdweb? index $=0 \&$ did $=748867451 \&$ Srch Mode $=1 \&$ sid $=6 \&$ Fmt $=2 \&$ VInst $=$ PROD $\&$ VType $=$ PQD \&RQT $=309$ $\&$ VName $=$ PQD\&TS $=1164158900 \&$ clientId $=29440$

[15] Guolla M. Assessing the teaching quality to student satisfaction relationship: applied customer satisfaction research in the classroom. J Mark Theory Pract 1999; 7: 87-98.

[16] Umbach PD, Porter SR. How do academic departments impact student satisfaction? Understanding the contextual effects of departments. Res High Educ 2002; 43: 209-34.

[17] Gill A, Biger N, Dhaliwal H. Building commitment to continue studies among Asian students. TOEDUCJ 2008; 1: 9-14.

[18] Klassen RM. A cross-cultural investigation of the efficacy beliefs of South Asian immigrant and Anglo Canadian nonimmigrant early adolescents. J Educ Psychol 2004; 96: 731-45.

[19] Davis D, DeValerio A. Increasing motivation and morality in education: does transformational leadership in K-12 schools affectteachers and students [Online]? Conference paper; 2006. Available from: http://www.allacademic.com/meta/p93222_index.html

[20] Niehoff BP, Enz CA, Growver RA. The impact of top-management actions on employee attitudes and perception. Group Organ Stud 1990; $15: 337-53$.

[21] Dubinsky AJ. A research odyssey in sales management. Acad Mark Sci Rev 1998; 1998: 1-6.

[22] Berson Y, Linton JD. An examination of the relationships between leadership style, quality, and employee satisfaction in $R \& D$ versus administrative environments. J R D Manag 2005; 35: 51-61.

[23] Seifrid JM. An analysis of leadership style and life stressors on marital satisfaction among conservative evangelical seminary students. The Southern Baptist Theological Seminary, AAT 2003.

[24] Marcus D. Long Island college freshmen find ways to adjust. Tribune Business News: Washington 2008.

[25] Murphy MC, Archer J. Stressors on the college campus: a comparison of 1985-1993. J Coll Stud Dev 1996; 37: 20-8. 
[26] Savery LK, Luks JA. The relationship between empowerment, job satisfaction, and reported stress levels: some Australian evidence. Leadersh Organ Dev J 2001; 22: 97-105.

[27] Tracy JB, Hinkin TR. Transformational leaders in the hospitality industry. J Cornell Hotel Restaur Adm Q 1994; 35: 18-24.

[28] Sax LJ. Health trends among college freshmen. J Am Coll Health 1997; 45: 252-62.

[29] LeRoy A. How to survive a nontraditional nursing student. Imprint 1988; 35: 73-86.

[30] Carveth JA, Gesse T, Moss N. Survival strategies for nursemidwifery students. J Nurse Midwifery 1996; 41: 50-4.

[31] Archer J, Lamnin A. An investigation of personal and academic stressors in college campuses. J Coll Stud Pers 1985; 26: 210-5.

[32] Kohn JP, Frazer GH. An academic stress scale: identification and rated importance of academic stressors. Psychol Rep 1986; 59: 415-26.

[33] Britton BK, Tesser A. Effects of time management practices on college grades. J Educ Psychol 1991; 83: 405-10.
[34] Abouserie R. Sources and levels of stress in relation to locus of control and self esteem in university students. Educ Psychol 1994; 14: 323-30.

[35] Sinha BK, Wilson LR, Watson DC. Stress and coping among students in India and Canada. Can J Behav Sci 2000; 32: 218-26.

[36] Gall M, Borg W, Gall J. Educational research: an introduction. $6^{\text {th }}$ ed. White Plains, NY: Longman Publishing 1996.

[37] Dubinsky AJ, Yammarino FJ, Jolson MA, Spangler WD. Transformational leadership: an initial investigation in sales context. Pers Selling Sales Manage 1995; 15: 15-31.

[38] Griffith J. Relation of principal transformational leadership to school staff job satisfaction, staff turnover, and school performance. J Educ Adm 2004; 42: 333-56.

[39] Thomas S. Ties that bind. J High Educ 2000; 71: 591-616.

[40] Bass BM, Avolio BJ. Manual: the multifactor leadership questionnaire. Palo Alto, CA: Consulting Psychologists Press 1989.

[41] Motowidlo SJ, Packard JS, Manning MR. Occupational stress: its causes and consequences for job performance. J Psychol 1986; 71 : 618-29.

(c) Gill et al.; Licensee Bentham Open.

This is an open access article licensed under the terms of the Creative Commons Attribution Non-Commercial License (http://creativecommons.org/licenses/by$\mathrm{nc} / 3.0 /$ ) which permits unrestricted, non-commercial use, distribution and reproduction in any medium, provided the work is properly cited. 